\title{
TINGKAT KECEMASAN ATLET AEROMODELLING KELAS FREE FLIGHT SETELAH MENGALAMI CEDERA BAHU MENJELANG PERTANDINGAN
}

\section{Oleh: \\ Mira Hayu Nindyowati dan Bambang Priyonoadi Pendidikan Kesehatan dan Rekreasi FIK UNY}

\begin{abstract}
Abstrak
Banyak atlet sering tidak percaya diri dalam melempar dan mengendalikan pesawatnya karena pernah mengalami cedera dan takut cedera pada bahu kembali kambuh saat pertandingan. Penelitian ini bertujuan untuk mengetahui seberapa tinggi tingkat kecemasan atlet aeromodelling kelas free flight setelah mengalami cedera bahu menjelang pertandingan di IST AKPRIND Flying Contest (IFC) Tahun 2016.

Penelitian ini merupakan penelitian deskriptif. Metode yang digunakan adalah survei dengan teknik pengambilan data menggunakan angket. Populasi dalam penelitian ini adalah atlet aeromodelling yang mengikuti IST AKPRIND Flying Contest (IFC) Tahun 2016 dan sampel diambil secara purposive sampling, dengan kriteria: (1) atlet aeromodelling yang mengikuti IST AKPRIND Flying Contest (IFC) Tahun 2016, (2) kelas free flight, (3) pernah mengalami cedera bahu. Berdasarkan kriteria tersebut yang memenuhi berjumlah 33 atlet. Instrumen yang digunakan adalah angket. Teknik analisis data menggunakan analisis deskriptif kuantitatif yang dituangkan dalam bentuk persentase.

Berdasarkan hasil penelitian maka dapat disimpulkan bahwa tingkat kecemasan atlet aeromodelling kelas free flight setelah mengalami cedera bahu menjelang pertandingan di IST AKPRIND Flying Contest (IFC) tahun 2016 berada pada kategori "rendah" 30,30 \% (10 atlet), "tinggi" 27,27 \% (9 atlet), "sedang" 24,24\% (8 atlet). Sedangkan hasil penelitian tingkat kecemasan untuk tiap faktor adalah sebagai berikut: 1) Faktor kognitif: kategori "tinggi" 39,39 \% (13 atlet), "rendah" 30,30 \% (10 atlet), "sedang" 21,21 \% (7 atlet), dan "sangat rendah" 9,09 \% (3 atlet). 2) Faktor somatik: kategori "rendah" 39,39 \% (13 atlet), "sedang" 33,33\% (11 atlet), "tinggi" 21,21 \% (7 atlet), dan sangat tinggi" 9,09\% (3 atlet). Simpulan dari hasil data penelitian ini ratarata tingkat kecemasan pada kategori "sedang".
\end{abstract}

Kata kunci: kecemasan, atlet aeromodelling kelas free flight, setelah cedera bahu

Aeromodelling merupakan salah satu cabang olahraga dirgantara yang tergabung dalam Persatuan Olahraga Dirgantara (PORDIRGA) di bawah naungan Federasi Aero Sport Indonesia (FASI). Olahraga aeromodelling ini mulai di kenal di masyarakat luas,banyaknya pecinta olahraga aeromodelling akhirnya mendirikan club-club di Indonesia. Olahraga aeromodelling ini bisa dimainkan dari orang tua, dewasa, muda, maupun anak-anak, dan tidak hanya kaum pria kaum wanita juga penggemar olahraga ini. Olahraga aeromodelling ini tidak hanya untuk menyalurkan hobi atau untuk fun (bersenang-senang), olahraga 
aeromodelling juga sebagai sarana menimba dan memperdalam ilmu pengetahuan, dan sebagai sarana pencapaian prestasi olahraga kedirgantaraan. Misalnya melalui olahraga ini seseorang dapat belajar tentang cara membuat pesawat, dan juga dapat memperoleh prestasi karena olahraga ini sudah dipertandingkan di tingkat nasional. Di Indonesia olahraga aeromodelling kini semakin berkembang hal ini dibuktikan dengan banyaknya even-even pertandingan.

Olahraga aeromodelling merupakan salah satu olahraga yang sering dipertandingkan mulai dari kejuaraan resmi, kejuaraan yang diselenggarakan di tingkat daerah dan nasional berdasarkan program kerja yang telah disusun oleh FASI (Federasi Aero Sport Indonesia) provinsi, KONI pusat serta disetujui dan diusulkan oleh PORDIRGA Aeromodelling PB FASI. Kejuaraan IST AKPRIND Flying Contest (IFC) Tahun 2016 dipertandingkan di Lanud Gading Wonosari, Gunung Kidul, Yogyakarta pada tanggal 10-13 Maret 2016. Kejuaraan IST AKPRIND Flying Contest ini kelas yang akan dipertandingkan yaitu kelas free flight dan pylon race. Kejuaraan ini dikuti oleh: (a) pelajar tingkat SD, SMP, SMA/SMK sederajat di Indonesia, (b) Mahasiswa di Indonesia, (c) Perwakilan dari propinsi seluruh Indonesia (d) perorangan/klub dalam atau luar negeri kategori umum.

Pada kejuaraan IST AKPRIND Flying Contest (IFC) kelas pertandingan yang banyak diminati, yaitu kelas free flight. Free flight merupakan terbang bebas yang terbagi menjadi tiga pesawat model, yaitu OHLG (Outdoor Hand Launched Glider), F1A (Glider A2), F1H (Glider A1). Kelas free flight dipertandingkan selama tiga hari, yaitu dari pagi hingga sore hari di lapangan terbuka (outdoor). Olahraga aeromodelling merupakan olahraga yang menantang fisik dan mental serta membawa risiko cedera. Cedera pada olahraga aeromodelling bisa terjadi disebabkan oleh berbagai hal, di antaranya kurangnya pemanasan sebelum latihan maupun pertandingan, melempar pesawat yang berulang-ulang dan berlebihan, serta latihan yang melebihi kapasitas tubuh (overtraining). Cedera olahraga dapat disebabkan oleh faktor dari dalam maupun faktor dari luar, hal tersebut diungkap oleh Arif Setyawan (2011: 95). Cedera olahraga diantaranya disebabkan oleh benturan pada saat latihan maupun pertandingan, kelemahan otot, overuse atau sarana prasarana yang kurang baik seperti kondisi lapangan yang memprihatinkan, bergelombang, berbatu, serta angin kencang.

Bagi sebagian orang cedera merupakan kejadian yang sangat menakutkan karena menimbulkan rasa sakit, rasa nyeri, selain itu menimbulkan rasa trauma yang sulit dilupakan. Atlet aeromodelling pada umumnya mempersepsikan cedera sebagai bentuk yang mengancam fisik dan berbahaya, serta memiliki respon yang berbeda-beda. Heil (1993: 34) 
mengungkapkan ketika atlet mengalami cedera sikap yang dikembangkan adalah diestress, denial, determined coping. Diestress berhubungan dengan respon emosional yang muncul seperti rasa kaget, cemas, marah, depresi, rasa bersalah, menarik diri, rasa malu, serta perasaan tidak berdaya. Denial berhubungan dengan tidak percaya akan kegagalan yang diterima sehingga mengarah untuk menolak keparahan cedera yang dialami. Determined coping merupakan fase permintaan kondisi cedera dan memahami dampak jangka panjang pendek terhadap karir olahraga atlet.Banyak aspek yang terkena dampak setelah seorang atlet mengalami cedera diantaranya aspek fisik, emosi, mental, dan aspek perilaku atlet yang bersangkutan. Apabila dilihat dari aspek emosi, respon atlet terhadap cedera adalah kecemasan, marah, frustasi, dan sebagainya. Kecemasan pada atlet yang memiliki riwayat cedera berbeda dengan atlet tanpa riwayat cedera.

Rasa cemas pada atlet dengan riwayat cedera berkembang karena mempersiapkan diri menghadapi tekanan dari pertandingan, atletpun harus mempersiapkan secara psikologis kesiapan fisiknya dalam menghadapi pertandingan. Ketika cedera maka atlet akan mengalami perubahan fisiologis seperti penegangan otot-otot, perubahan psikologis seperti perkembangan rasa cemas hingga depresi. Hubungan kecemasan dengan pertandingan diungkapkan Cartty (Husdarta: 2011: 75) sebagai berikut: (a) pada umumnya kecemasan meningkat sebelum bertanding yang disebabkan oleh bayangan beratnya tugas dan pertandingan yang akan datang. (b) selama Pertandingan di berlangsung, tingkat kecemasan mulai menurun karena sudah mulai adaptasi. (c) mendekati akhir pertandingan, kecemasan mulai naik lagi, terutama apabila skor pertandingan sama atau hanya berbeda sedikit.

Kecemasan merupakan suatu kondisi yang hampir dialami semuah atlet aeromodelling.Hal ini karena olahraga aeromodelling, merupakan olahraga outdoor yang dipertandingkan dari pagi hingga sore, sehingga membuat para atlet lelah seharian dan mencemaskan hasil akhir pertandingan yang sama atau berbeda dengan tim lain. Penonton dan atlet aeromodeling tim lain pun sering berteriak-teriak untuk mengecoh lawannya saat menerbangkan dan mengendalikan pesawat sehingga membuat atlet bingung, kesal dan tidak percaya diri dalam menerbangkan pesawatnya. Oleh karena itu jarang sekali atlet memiliki rasa percaya diri dalam pertandingan, terlebih atlet yang sudah pernah mengalami cedera. 


\section{KAJIAN PUSTAKA}

\section{Definisi Kecemasan}

Kecemasan merupakan reaksi situasional terhadap berbagai rangsangan stres. Cashmore (2002) (dalam Rizki Mahakharisma, 2014: 8) menyatakan bahwa kecemasan mengacu kepada emosi yang tidak menyenangkan dan ditandai dengan perasaan samar, tetapi terus menerus merasa prihatin dan kekuatan. Kecemasan adalah ketegangan mental disertai dengan gangguan tubuh yang menyebabkan individu bersangkutan merasa tidak berdaya dan mengalami kelelahan karena senantiasa harus berada dalam keadaan waspada terhadap ancaman bahaya yang tidak jelas (Komarudin, 2015: 102). Levitt yang dikutip oleh Husdarta (2011: 73) menyatakan "Kecemasan dapat didefinisikan sebagai suatu perasaan subjektif terhadap sesuatu yang ditandai oleh kekhawatiran, ketakutan, ketegangan, dan meningkatkan kegairahan secara fisiologik." Setiap orang pernah mengalami kecemasan atau ketakutan terhadap berbagai situasi seperti takut dimarahi, takut tidak naik kelas, takut gagal, takut tertabrak dan takut atau khawatir sebelum bertanding. Adapun Singgih D. Gunarsa (2008: 147) menambahkan kecemasan adalah perasaan tidak berdaya, tak aman tanpa sebab yang jelas, kabur atau samar-samar. Kecemasan dalam pertandingan akan menimbulkan tekanan emosi yang berlebihan yang dapat mengganggu pelaksanaan pertandingan serta mempengaruhi penampilan atau prestasi.

Rita L. Atkinson (1993: 212) menyatakan kecemasan emosi adalah yang tidak menyenangkan, yang ditandai dengan istilah-istilah seperti kekhawatiran, keprihatinan, dan rasa takut yang terkadang-kadang dialami dalam tingkat yang berbeda dalam kecemasan, orang dapat menggunakan tenaga emosional dari pada yang disadari. Hal senada Sudibyo Setyabrata (1993: 110) menyatakan rasa cemas adalah suatu perasaan subjektif akan ketakutan dan meningkatkan kegairahan secara fisiologis.

Berdasarkan beberapa pengertian di atas dapat disimpulkan bahwa kecemasan adalah perasaan yang menimbulkan tekanan emosi yang dialami oleh siapa saja, kapan saja, dan di mana saja saat menghadapi suatu keadaan yang penting, misalnya menghadapi suatu pertandingan. Perasaan cemas muncul dalam diri atlet disebabkan oleh faktor intrinsik maupun ekstrinsik sehingga dapat mempengaruhi penampilan atlet saat menghadapi pertandingan yang akan dihadapi. Gambaran asumsi seperti membayangkan musuh yang lebih kuat, tentang kondisi fisik yang tidak cukup bagus, even yang sangat besar atau semua orang menaruh harapan yang berlebihan bisa mengakibatkan kecemasan yang berlebihan. 


\section{Jenis Kecemasan}

Jenis-jenis gangguan kecemasan dapat digolongkan menjadi beberapa pendekatan. Wiramiharja (Wisnu Haruman, 2013: 23) mengungkapkan beberapa jenis gangguan kecemasan sebagai berikut:

1. Panic disorder yaitu gangguan yang dipicu oleh munculnya satu atau dua serangan atau panik yang dipicu oleh hal-hal yang menurut orang lain bukan merupakan peristiwa yang luar biasa. Agrofobia yaitu suatu keadaan seseorang merasa tidak dapat atau sukar menjadi baik secara fisik maupun psikologis untuk melepas diri.

2. Phobia lainnya merupakan pernyataan perasaan cemas atau takut atas suatu yang tidak jelas, tidak rasional, tidak realistis.

3. Obsesive-compulsive yaitu suatu pikiran yang terus menerus secara patologis muncul dari dalam diri seseorang, sedangkan komplusif adalah tindakan yang didorong oleh impuls yang berulang kali dilakukan.

4. Gangguan kecemasan tergenerelisasikan yang ditandai adanya rasa khawatir yang eksesif dan kronis dalam istilah lama disebut Free Floating Anxiety.

Husdarta (2011: 80) menyatakan kecemasan yang dirasakan oleh atlet dalam waktu tertentu, misalnya menjelang pertandingan (state anxiety) dan kecemasan yang dirasakan karena atlet tergolong pencemas (trait anxiety). Satiadarma (2000: 11) menyatakan bahwa dalam dunia olahraga kecemasan (anxiety), gugahan (arousal), dan stres (stress) merupakan aspek yang memiliki kaitan yang sangat erat satu sama lain sehingga sulit dipisahkan. Charles Spielberger (1966) (Singgih D. Gunarsa, 2008: 74) membagi kecemasan menjadi dua, yaitu

1. State Anxiety adalah suatu keadaan emosional berupa ketegangan dan ketakutan yang tiba-tiba muncul, serta diikuti perubahan fisiologi tertentu. Munculnya kecemasan antara lain ditandai gerakan-gerakan pada bibir, sering mengusap keringat pada telapak tangan, atau pernapasan yang terlihat tinggi. State anxiety merupakan keadaan objektif ketika seseorang mempersepsikan rangsangan-rangsangan lingkungan, dalam hal ini pertandingan, sebagai sesuatu yang memang menimbulkan ketegangan atau kecemasan.

2. Trait Anxiety adalah suatu predisposisi untuk mempresepsikan situasi lingkungan yang mengancam dirinya. Spielberger (1966) merumuskan trait anxiety sebagai berikut: Jika seorang atlet pada dasarnya memiliki trait anxiety, maka manifestasinya kecemasannya akan selalu berlebihan dan mendomonasi aspek psikis. Hal ini merupakan kendala yang serius bagi atlet tersebut untuk berpenampilan baik. 
Komarudin (2015: 13) menyatakan kecemasan somatik (somatic anxiety) adalah perubahan-perubahan fisiologis yang berkaitan dengan munculnya rasa cemas. Somatic anxiety ini merupakan tanda-tanda fisik saat seseorang mengalami kecemasan. Tanda-tanda tersebut antara lain: perut mual, keringat dingin, kepala terasa berat, muntah-muntah, pupil mata melebar, otot menegang, dan sebagainya. Untuk mengukur kecemasan jenis ini dibutuhkan pemahaman yang mendalam dari atlet terhadap kondisi tubuhnya. Atlet harus selalu sadar dengan kondisi fisik yang rasakan.

Kecemasan kognitif (cognitive anxiety) adalah pikiran-pikiran cemas yang muncul bersamaan dengan kecemasan somatis. Pikiran-pikiran cemas tersebut antara lain: kuatir, ragu-ragu, bayangan kekalahan atau perasaan malu. Pikiran-pikiran tersebut yang membuat seseorang selalu merasa dirinya cemas. Kedua jenis rasa cemas tersebut terjadi secara bersamaan, artinya ketika seorang atlet mempunyai keraguraguan saat akan bertanding, maka dalam waktu yang bersamaan dia akan mengalami kecemasan somatis, yakni dengan adanya perubahan-perubahan fisiologis.

\section{Kecemasan pada Cedera Berulang}

Heil (1993: 34) menyatakan bahwa kecemasan kembali cedera adalah hal yang normal bagi setiap atlet yang baru saja pulih dari cederanya. Kecemasan merupakan respon atlet yang lebih kognitif, bentuk proses belajar sosial serta berhubungan dengan atisipasi atlet terhadap sesuatu yang tidak nyata secara fisik (Hakcfort \& Schwenkmezger, dalam Walker, Thetcher, \& Lavalle, 2009). Istilah kecemasan dianggap sesuai dengan keadaan atlet yang baru pulih dari cedera, karena merupakan gambaran dari perasaan dan penilaian atlet terhadap riwayat cedera yang pernah dialami. Hal yang dianggap sebagai ancaman tidak nyata secara fisik karena dalam kenyataanya cedera tersebut sudah pulih. Kecemasan ini berdampak secara fisiologis dan psikologis yang akan terlihat pada performance atlet. Gould (1997) dalam Podlog dan Eklund (2007) yang dikutip oleh Damar Arum Dwiariani (2012: 17)mengemukakan beberapa perilaku yang muncul berhubungan dengan kecemasan cedera berulang antara lain:

1. Mudah ragu-ragu.

2. Kurang mengeluarkan usaha dan tenaga yang maksimal.

3. Sangat melindungi bagian yang pernah cedera dengan melilitkan tapping dengan kuat atau memakai pelindung selalu.

4. Cenderung sangat berhati-hati dengan situasi yang dapat memicu terjadinya cedera.

5. Memiliki kesadaran yang sangat tinggi terhadap kelemahan fisik yang mereka alami.

6. Takut tidak mampu memenuhi harapan orang lain.

7. Khawatir tidak mampu membanggakan atau menaikan reputasi tim ataupun pelatih.

8. Merasa kurang mendapatkan empati atau perhatian dari orang lain.

9. Hubungan yang kurang baik dengan teman satu tim. 
10. Secara fisik performance atau penampilannya selalu buruk.

11. Kurang aktif secara fisik.

12. Mudah marah atau sensitif.

13. Terburu-buru dalam mengambil keputusan.

14. Memiliki rasa takut akan kegagalan.

\section{Pengertian Aeromodelling}

Aeromodelling berasal dari dua kata yaitu "Aero" yang berarti Udara dan "Model"yang berarti Model, contoh, tiruan. Aeromodelling adalah suatu kegiatan yang mempergunakan sarana miniatur (model) pesawat terbang untuk tujuan rekreasi, edukasi dan olahraga (Artikel FASI, 2006). Menurut Pordirga Aeromodelling PB FASI (2009: 4) aeromodelling adalah kegiatan perancangan, pembuatan dan penerbangan pesawat model yang lebih berat dari udara (heavier than air) dimana gaya-gaya angkat yang diperoleh dari permukaan sayap dengan ukuran yang tertentu dengan atau tanpa motor dan tidak dapat membawa manusia. Olahraga aeromodelling merupakan salah satu cabang olahraga dirgantara yang tergabung dalam Persatuan Olahraga Dirgantara (PORDIRGA) di bawah naungan Federasi Aero Sport Indonesia (FASI). Aeromodelling adalah suatu kegiatan yang melibatkan unsur-unsur dari mulai perencanaan, pembuatan, pengetesan, sampai pada penerbangan pesawat model. Pesawat aeromodelling adalah pesawat model yang lebih berat dari udara dengan ukuranukuran terbatas, baik bermotor/bermesin maupun yang tidak dapat diawaki oleh manusia.

Orang yang terlibat dalam kegiatan aeromodelling disebut aeromodeller. Kriteria sebagai penyandang predikat aeromodeller harus mengetahui, mengerti, dan menguasai ilmu dasar pendukung, misalnya: aerodinamika, ilmu gaya, fisika, dan lain sebagainya. Juga mampu berkarya desain dan menerbangkan. Federasi Aero Sport Indonesia (2006), peminat dari aeromodelling ini terbagi menjadi 3 kategori, yaitu: yang tergabung dalam kategori aeromodelling yang hanya untuk bersenang-senang (fun), aeromodelling sebagai sarana menimba dan memperdalam ilmu pengetahuan, dan aeromodelling sebagai sarana pencapaian prestasi olah raga kedirgantaraan. Olahraga ini bisa dimainkan dari anak-anak, remaja, dewasa, maupun orang tua. Kelas terbang bebas atau biasanya di sebut glider, yaitu menerbangkan pesawat model dengan cara melemparkan pesawat dengan menggunakan tangan manusia. Pesawat model dengan kelas ini tidak dilengkapi oleh tenaga penggerak (motor listrik atau piston). Untuk mendapatkan gaya dorong kedepan dengan menggunakan gaya angkat (lift) yang dihasilkan hanya didapat dari permukaan aerodinamis yang bersifat tetap (tidak dapat digerakan) (Artikel FASI, 2006). Area penerbangan pesawat ini bisa dilakukan di lapangan terbuka dengan beberapa pertimbangan yaitu: (a) Kekuatan angin yang 
cukup, (b) Arah angin sebagai acuan arah penerbangan dan pendaratan pesawat model, (c) Area yang relatif jauh dari bangunan, jalan raya dan parkiran.

\section{Pengertian Cedera}

Cedera adalah kelainan yang terjadi pada tubuh yang mengakibatkan timbulnya nyeri, panas, merah, bengkak, dan tidak dapat berfungsi baik pada otot, tendon, ligamen, persendian ataupun tulang akibat aktivitas gerak yang berlebihan atau kecelakaan (Ali Satia Graha dan Bambang Priyonoadi, 2012: 29). Cedera merupakan rusaknya jaringan yang disebabkan adanya kesalahan teknis, benturan, atau aktivitas fisik yang melebihi batas beban latihan, yang dapat menimbulkan rasa sakit akibat dari kelebihan latihan melalui pembebanan latihan yang terlalu berat sehingga otot dan tulang tidak lagi dalam keadaan anatomis (Cava,1995: $145)$.

Cedera olahraga diungkapkan Andun Sudijandoko (2000:7) adalah rasa sakit yang ditimbulkan karena olahraga, yang dapat menimbulkan cacat, luka, dan rusak pada otot atau sendi serta bagian lain dari tubuh. Cedera olahraga adalah segala macam cedera yang timbul pada waktu latihan ataupun pada waktu pertandingan ataupun sesudah pertandingan (Hardianto Wibowo,1995:11). Berdasarkan pengertian di atas, maka dapat disimpulkan bahwa cedera dapat diartikan sebagai suatu keadaan tubuh mengalami kerusakan yang disebabkan karena paksaan dalam melakukan gerakan atau tekanan dari luar tubuh. Respon yang umumnya timbul saat cedera menurut (Eubank dan Nicholas, 2001) yang dikutip oleh

(Damar Arum Dwiariani 2012: 12) yaitu:

1) Injury relevan information processing, yaitu respon yang terfokus pada rasa sakit yang dialami, memikirkan akibat terburuk yang mungkin dialami dari cedera tersebut, dan terus mempertanyakan riwayat cedera tersebut terjadi.

2) Emotional upheaval and reactive behaivor, yaitu bentuk respon emosional yang ditunjukan oleh atlet seperti mengasihani diri sendiri, penolakan, tidak percaya diri, sensitif, depresi dan mudah marah.

3) Identity loss, yaitu merupakan tahapan respon terhadap cedera yang dalam teori Rotella (1985) dinyatakan sebagai masa-masa kehilangan. Atlet akan mempresepsikan cedera sebagai sesuatu yang mengambil semua hal yang rutin dalam kehidpannya sehingga ia sangat merasa kehilangan jati dirinya. Seorang atlet sangat bergantung pada keterampilan fisik sehingga saat mengalami cedera, atlet terpaksa menghentikan aktivitas rutin mereka dan merasa hidup dalam kondisi yang tidak pasti dan merasa posisinya terancam.

4) Isolation, atlet akan merasa kesepian karena intensitas hubungan dengan rekan satu tim menjadi berkurang. Dukungan sosial yang penting bagi atlet dirasakan hilang dari kehidupannya.

5) Rasa takut dan cemas, timbul karena atlet hidup dalam ketidak pastian akan masa depannya. Memikirkan apakah kesembuhannya akan total, kemungkinan cedera berulang, posisi dirinya akan digantikan oleh orang lain atau mempertanyakan diri apakah mampu mereka untuk kembali bermain lagi. Kurang percaya diri dan menurunya performence, atlet meragukan kekuatan fisiknya sehingga mereka menjadi lebih berhati-hati dan sangat 
melindungi area yang pernah cedera. Hal ini kan semakin mengarahkan atlet untuk mengembangkan rasa frustasi dan cemas

6)

\section{Cedera Bahu}

Cedera yang terjadi pada tubuh mengakibatkan timbulnya nyeri, panas, merah, bengkak, dan tidak dapat berfungsi baik pada otot, tendon, ligamen, persendian ataupun tulang akibat aktivitas gerak yang berlebihan atau kecelakaan (Ali Satia Graha dan Bambang Priyonoadi, 2012: 29).Cedera olahraga adalah segala macam cedera yang timbul pada waktu latihan ataupun pada waktu pertandingan ataupun sesudah pertandingan (Hardianto Wibowo,1995:11). Bahu memungkinkan untuk bergerak sangat bebas dalam melakukan berbagai macam jangkauan gerakan, sehingga sendi ini merupakan persendian yang sangat tidak stabil dan mudah mengalami cedera (Reed, Presley, 2005: 215).

Sendi bahu adalah sendi yang dibentuk oleh caput humeri dan cavitas glenoidalis scapulae.Berdasarkan bentuk permukaan tulang yang bersendi, maka articulation humeri terasuk sendi peluru (articulation globoidea/spheroidea).Berdasarkan jumlah aksisnya sendi bahu termasuk sendi triaksial yang mempunyai tiga aksis yaitu aksis sagital, transversal dan aksis longitudinal. Menurut Lynn Millar (2011: 103) bahwa sendi bahu merupakan ciptaan yang luar bisa yang tersusun secara komples oleh tulang, otot, dan tendo yang menghasilkan gerakan ROM yang luas karena disusun tulang berbentuk seperti bola.Sendi bahu diselubungi oleh kantung jaringan kuat disebut kapsul, yang berfungsi untuk menyatukan sendi.Empat grup otot dan tendonnya membuat rotator cuff, yang mengatur gerakan dan juga untuk membantu agar sendi tidak lepas.Terdapat sendi yang berukuran lebih kecil yang terletak diatas bahu yang bertugas untuk mengikat tulang clavicula.

Bahu memungkinkan untuk bergerak sangat bebas dalam melakukan berbagai macam jangkauan gerakan, sehingga sendi ini merupakan persendian yang sangat tidak stabil dan mudah mengalami cedera (Reed, Presley, 2005: 215).Lynn Millar (2011: 104) menjelaskan bahwa terdapat dua faktor utama penyebab terjadinya cedera pada bahu. Pertama adalah karena faktor degenerasi, atau yang lebih umum terjadi yaitu karena terjadi peregangan dan perobekan.Penyebab kedua adalah latihan terus menerus yang terlalu dipaksakan.Hal ini terjadi saat mengangkat beban yang berat dengan posisi lengan yang salah atau kurang nyaman. Menurut Sufitni (2004: 1) cedera bahu dapat disebabkan oleh beberapa hal diantaranya:

1) Cedera bahu/nyeri bahu yang diakibatkan karena aktifitas fisik, misalnya: cedera saat bermain bola voli, renang, bulu tangkis, tolak peluru atau aktivitas lain. Cedera kemungkinan terjadi pada otot, ligament, tendon, dan sendi. 
2) Cedera bahu/ nyeri bahu karena hentakan mendadak pada sendi bahu sedang otot pada waktu itu tidak kuat dan tidak siap, misalnya: tumpuan salah, terbentur, gerakan berlebih dan lain-lain. Cedera kemungkinan terjadi pada sendi/ dislokasi sendi. Nyeri Bahu yang disinyalir karena kebiasaan buruk, misalnya: tidak pernah melakukan pemanasan sebelum melakukan aktivitas latihan, terlalu banyak menggunakan beban latihan, mengangkat benda berat, dan sebagainya. Cedera kemungkinan terjadi pada otot dan syaraf.

3) Cedera pada bahu yang disebabkan karena lelah, tetapi sering juga terjadi pada pemain tennis, badminton, olahraga lempar dan berenang (internal violence/sebab-sebab yang berasal dari dalam). Cedera ini bisa juga disebabkan oleh external violence (sebab-sebab yang berasal dari luar), akibat body contact sports, misalnya: sepakbola, rugby, dan lainlain.

Cartty (Husdarta, 2011: 75) menyatakan hubungan antara kecemasan dengan pertandingan sebagai berikut: (a) pada umumnya kecemasan meningkat sebelum bertanding yang disebabkan oleh banyangan beratnya tugas dan pertandingan yang akan dating, (b) selama pertandingan berlangsung, tingkat kecemasan mulai menurun karena sudah mulai adaptasi, (c) mendekati akhir pertandingan, kecemasan mulai naik lagi, terutama apabila skor pertandingan sama atau hanya berbeda sedikit. Berdasarkan pemaparan di atas, sebaiknya mengetahui sumber-sumber kecemasan yang dialami oleh atlet, sehingga dapat menekan gejala-gejala kecemasan tersebut, demi terciptanya prestasi secara optimal. Berikut ini gambar cedera pada bahu:

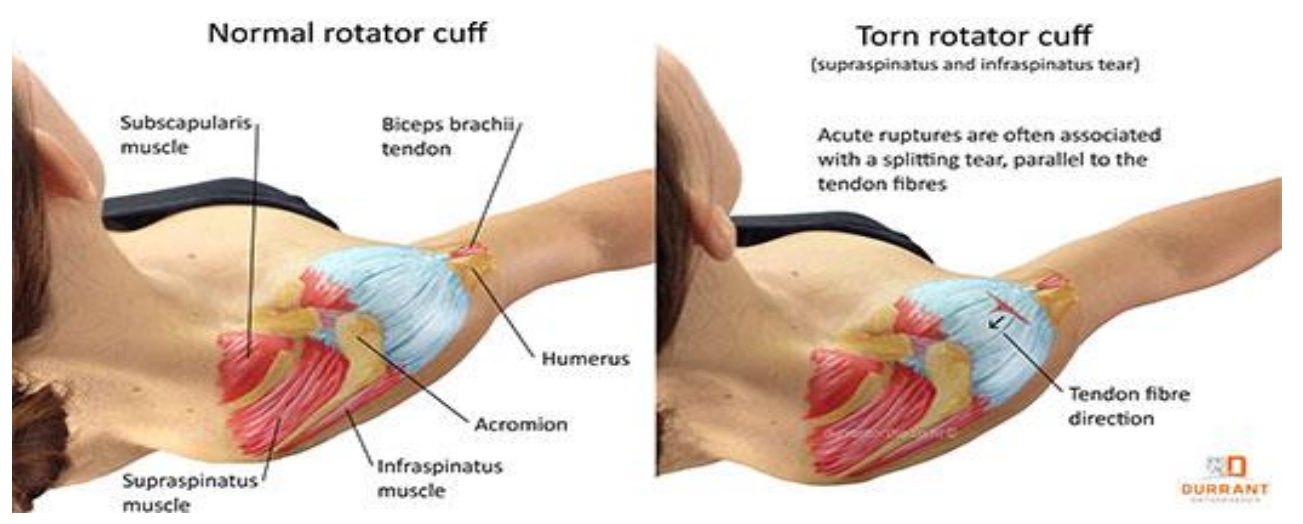

Gambar 1. Cedera pada Bahu (http://doktertulangbelakangsingapura.com/kondisi/nyeri-bahu)

\section{METODE PENELITIAN}

Jenis penelitian ini adalah penelitian deskriptif. Metode yang digunakan adalah survei teknik pengumpulan data menggunakan angket. Populasi dalam penelitian ini adalah atlet aeromodelling yang mengikuti IST AKPRIND Flying Contest (IFC) Tahun 2016 yang berjumlah 190 atlet. Teknik sampling dalam penelitian yaitu dengan purposive sampling. Kriteria dalam penentuan sampel ini meliputi: (1) atlet aeromodelling yang mengikuti IST 
AKPRIND Flying Contest (IFC) Tahun 2016, (2) kelas free flight, (3) pernah mengalami cedera bahu. Berdasarkan kriteria tersebut yang memenuhi berjumlah 33 atlet.

\section{HASIL PENELITIAN}

Hasil penelitian ini dimaksudkan untuk menggambarkan data, yaitu tentang tingkat kecemasan atlet aeromodelling kelas free flight setelah mengalami cedera bahu menjelang pertandingan di IST AKPRIND Flying Contest (IFC) tahun 2016yang diungkapkan dengan angketyang berjumlah 49 butir,dan terbagi dalam dua faktor, yaitu faktor kognitif dan somatik. Hasil analisis data penelitian tingkat kecemasan atlet aeromodelling kelas free flight setelah mengalami cedera bahu menjelang pertandingan IST AKPRIND Flying Contest (IFC) tahun 2016dipaparkan sebagai berikut: Distribusi frekuensi data hasil penelitian tentang tingkat kecemasan atlet aeromodelling kelas free flight setelah mengalami cedera bahu menjelang pertandingan di dapat skor terendah (minimum) 66,0, skor tertinggi (maksimum) 163,0, rerata (mean) 115,97, nilai tengah (median) 118,0, nilai yang sering muncul (mode) 88,0 , standard deviasi (SD) 30,29. Hasil selengkapnya dapat dilihat pada tabel 1 sebagai berikut:

\section{Tabel 1.Deskriptif Statistik Tingkat Kecemasan}

\begin{tabular}{|l|r|}
\hline \multicolumn{2}{|c|}{ Statistik } \\
\hline$N$ & 33 \\
\hline Mean & 115.9697 \\
\hline Median & 118.0000 \\
\hline Mode & $88.00^{\mathrm{a}}$ \\
\hline Std, Deviation & 30.29798 \\
\hline Minimum & 66.00 \\
\hline Maximum & 163.00 \\
\hline
\end{tabular}

Apabila ditampilkan dalam bentuk distribusi frekuensi, tingkat kecemasan atlet aeromodelling kelas free flight setelah mengalami cedera bahu menjelang pertandingan di IST AKPRIND Flying Contest (IFC) tahun 2016 disajikan pada tabel 2 sebagai berikut:

Tabel 2. Distribusi Frekuensi Tingkat Kecemasan Atlet Aeromodelling Kelas Free Flight Setelah Mengalami Cedera Bahu Menjelang Pertandingan

\begin{tabular}{|c|c|c|c|c|}
\hline No & Interval & Kategori & Frekuensi & $\%$ \\
\hline 1 & $161,42<X$ & Sangat Tinggi & 3 & $9,09 \%$ \\
\hline 2 & $131,12<X \leq 161,42$ & Tinggi & 9 & $27,27 \%$ \\
\hline 3 & $100,82<X \leq 131,12$ & Sedang & 8 & $24,24 \%$ \\
\hline 4 & $70,52<X \leq 100,82$ & Rendah & 10 & $30,30 \%$ \\
\hline 5 & $X \leq 70,52$ & Sangat Rendah & 3 & $9,09 \%$ \\
\hline \multicolumn{3}{|c|}{ Jumlah } & 33 & $100 \%$ \\
\hline
\end{tabular}




\section{Faktor Kognitif}

Distribusi frekuensi data hasil penelitian tentang tingkat kecemasan atlet aeromodelling kelas free flight setelah mengalami cedera bahu menjelang pertandingan di IST AKPRIND Flying Contest (IFC) tahun 2016 berdasarkan faktor kognitif didapat skor terendah (minimum) 33,0,skor tertinggi (maksimum) 84,0, rerata (mean) 61,64, nilai tengah (median) 59,0, nilai yang sering muncul (mode) 46,0, standar deviasi (SD) 16,79. Hasil selengkapnya dapat dilihat pada tabel 3 berikut:

\section{Tabel 3. Deskriptif StatistikTingkat Kecemasan Berdasarkan Faktor Kognitif}

\begin{tabular}{|l|r|}
\hline \multicolumn{2}{|c|}{ Statistik } \\
\hline$N$ & 33 \\
\hline Mean & 61.6364 \\
\hline Median & 59.0000 \\
\hline Mode & 46.00 \\
\hline Std, Deviation & 16.79066 \\
\hline Minimum & 33.00 \\
\hline Maximum & 84.00 \\
\hline
\end{tabular}

Apabila ditampilkan dalam bentuk distribusi frekuensi, tingkat kecemasan atlet aeromodelling kelas free flight setelah mengalami cedera bahu menjelang pertandingan di IST AKPRIND Flying Contest (IFC) tahun 2016 berdasarkan faktor kognitif disajikan pada tabel 4 berikut:

Tabel 4. Distribusi Frekuensi Tingkat Kecemasan Atlet Berdasarkan Faktor Kognitif

\begin{tabular}{|c|c|c|c|c|}
\hline $\mathbf{N}$ & Interval & Kategori & Frekuensi & $\%$ \\
\hline 1 & $86,82<X$ & Sangat Tinggi & 0 & $0 \%$ \\
\hline 2 & $70,03<X \leq 86,82$ & Tinggi & 13 & $39,39 \%$ \\
\hline 3 & $53,24<X \leq 70,03$ & Sedang & 7 & $21,21 \%$ \\
\hline 4 & $36,45<X \leq 53,24$ & Rendah & 10 & $30,30 \%$ \\
\hline 5 & $X \leq 36,45$ & Sangat Rendah & 3 & $9,09 \%$ \\
\hline \multicolumn{3}{|c|}{ Jumlah } & 33 & $100 \%$ \\
\hline
\end{tabular}

\section{Faktor Somatik}

Distribusi frekuensi data hasil penelitiantentang tingkat kecemasan atlet aeromodelling kelas free flight setelah mengalami cedera bahu menjelang pertandingan di IST AKPRIND Flying Contest (IFC) tahun 2016 berdasarkan faktor somatik didapat skor terendah (minimum) 33,0,skor tertinggi (maksimum) 80,0, rerata (mean) 54,33, nilaitengah (median) 57,0, nilai yang sering muncul (mode) 59,0, standardeviasi (SD) 14,32. Hasil selengkapnya dapat dilihat pada tabel 5 sebagai berikut: 
Tabel 5. Deskriptif StatistikTingkat Kecemasan Berdasarkan Faktor Somatik

\begin{tabular}{|l|r|}
\hline \multicolumn{2}{|c|}{ Statistik } \\
\hline$N$ & 33 \\
\hline Mean & 54.3333 \\
\hline Median & 57.0000 \\
\hline Mode & 59.00 \\
\hline Std, Deviation & 14.32364 \\
\hline Minimum & 33.00 \\
\hline Maximum & 80.00 \\
\hline
\end{tabular}

Apabila ditampilkan dalam bentuk distribusi frekuensi, tingkat kecemasan atlet aeromodelling kelas free flight setelah mengalami cedera bahu menjelang pertandingan di IST AKPRIND Flying Contest (IFC) tahun 2016 berdasarkan faktor somatikdisajikan pada tabel 6 berikut:

Tabel 6. Distribusi Frekuensi Tingkat Kecemasan Atlet Berdasarkan Faktor Somatik

\begin{tabular}{|c|c|c|c|c|}
\hline No & Interval & Kategori & Frekuensi & $\%$ \\
\hline 1 & $75,82<X$ & Sangat Tinggi & 3 & $9,09 \%$ \\
\hline 2 & $61,50<X \leq 75,82$ & Tinggi & 6 & $18,18 \%$ \\
\hline 3 & $47,17<X \leq 61,50$ & Sedang & 11 & $33,33 \%$ \\
\hline 4 & $32,85<X \leq 47,17$ & Rendah & 13 & $39,39 \%$ \\
\hline 5 & $\mathrm{X} \leq 32,85$ & Sangat Rendah & 0 & $0 \%$ \\
\hline \multicolumn{3}{|c|}{ Jumlah } & 33 & $100 \%$ \\
\hline
\end{tabular}

\section{PEMBAHASAN}

Penelitian ini bertujuan untuk mengetahui tentang tingkat kecemasan atlet aeromodelling kelas free flight setelah mengalami cedera bahu menjelang Pertandingan di IST AKPRIND Flying Contest (IFC) tahun 2016 yang berdasarkan hasil analisis keseluruhan faktor kecemasan, faktor kognitif dan somatik. Hasil analisis data keseluruhan penelitian dari faktor kecemasan menunjukkan bahwa tingkat kecemasan atlet aeromodelling kelas free flight setelah mengalami cedera bahu menjelang pertandingan di IST AKPRIND Flying Contest (IFC) tahun 2016 berada pada kategori "rendah" sebesar 30,30 \% (10 atlet), "tinggi" sebesar $27,27 \%$ (9 atlet), "sedang" sebesar 24,24 \% (8 atlet), "sangat rendah" sebesar 9,09\% (3 atlet), dan "sangat tinggi" sebesar 9,09 \% (1 atlet). Seperti yang diungkapkan pada hasil penelitian Febiaji (2014: vii) bahwa tingkat kecemasan atlet sepakbola faktor dari luar sangat tinggi. Seorang atlet yang menglami kecemasan berlebih dalam pertandingan kemungkinan dapat menimbulkan kecemasan dalam bentuk gangguan kesehatan atau penyimpangan tingkah laku sehingga penampilan dan rasa percaya dirinya akan menurun dan tingkat konsentrasinya akan berkurang. Komarudin (2015: 102) indikator yang bisa dijadikan bahwa atlet mengalami kecemasan bisa dilihat dari perubahan secara fisik maupun secara 
psikis."Gejala-gejala kecemasan secara fisik di antaranya: (a) adanya perubahan yang dramatis pada tingkah laku, gelisah atau tidak tenang dan sulit tidur, (b) terjadinya peregangan otot-otot pundak, leher, perut, terlebih lagi pada otot-otot ekstremitas, (c) terjadi perubahan irama pernapasan, (d) terjadinya kontraksi otot setempat, pada dagu, sekitar mata dan rahang; sedangkan gejala secara psikis yaitu: (a) gangguan perhatian dan konsentrasi; (b) perubahan emosi; (c) menurunnya rasa percaya diri; (d) timbul obsesi; (e) tidak ada motivasi".

Kecemasan akan mempengaruhi atlet aeromodelling, salah satunya adalah faktor kognitif. Hasil analisis data dari penelitian tingkat kecemasan berupa faktor kognitif yang dilakukan dalam penelitian ini didapat yaitu kategori "tinggi" sebesar 39,39 \% (13 atlet), "rendah" sebesar 30,30 \% (10 atlet), "sedang" sebesar 21,21 \% (7 atlet), "sangat rendah" sebesar 9,09\% (3 atlet), dan "sangat tinggi" sebesar $0 \%$ (0 atlet). Hasil analisis rata-rata data di atas menunjukkan kategori sedang 61,64. Penelitian ini diperkuat oleh Febiaji (2013: vii) dari faktor instrinsik pada pemain sepakbola dikategorikan sedang sekitar 21,94\%. Dikarenakan tingkat kecemasan timbul pikiran cemas, seperti kuatir, ragu-ragu, bayangan kekalahan atau perasaan malu (Komarudin, 2015: 13). Kecemasan kognitif yang muncul bersama dengan kecemasan somatik dapat dilihat hasil analisis data penelitian ini yaitu pada somatik kategori "rendah" sebesar 39,39 \% (13 atlet), "sedang" sebesar 33,33\% (11 atlet), “tinggi" sebesar 21,21\% (7 atlet), sangat tinggi" sebesar 9,09 \% (3 atlet), dan "sangat rendah" sebesar $0 \%$ (0 atlet). Penelitian ini diperkuat oleh Febiaji (2013: vii) dari faktor instrinsik 78,06 \%. Dikarenakan kecemasan somatik merupakan tanda-tanda fisik saat seseorang mengalami kecemasan, tanda-tanda tersebut antara lain: perut mual, keringat dingin, kepala terasa berat, muntah-muntah, pupil mata melebar, otot menegang, dan sebagainya.

Singgih D. Gunarsa (2008: 67) menyatakan seorang atlet biasanya takut sebelum menghadapi pertandingan, takut gagal memenuhi harapan pelatih, teman, dan keluarga. Walaupun ada kemungkinan takut mengalami cedera atau mungkin takut oleh perasaan diasingkan, diejek dan lain bila gagal dalam suatu pertandingan. Seorang atlet yang terlalu cemas menghadapi suatu pertandingan adalah atlet yang tidak mampu mengatasi permasalahannya dengan baik. Atlet tersebut secara psikologis sudah kalah sebelum bertanding, namun kecemasan yang dialami atlet tidak selamanya mengganggu atau merugikan dalam keadaan tertentu kecemasan dapat memberi nilai lebih bahkan diperlukan untuk mencapai prestasi yang optimal. 


\section{KESIMPULAN}

Kecemasan yang dirasakan oleh atlet dalam waktu tertentu, misalnya menjelang pertandingan (state anxiety) dan kecemasan yang dirasakan karena atlet tergolong pencemas (trait anxiety). Dalam dunia olahraga kecemasan (anxiety), gugahan (arousal), dan stres (stress) merupakan aspek yang memiliki kaitan yang sangat erat satu sama lain sehingga sulit dipisahkan. Berdasarkan hasil analisis data dan pembahasan, dapat diambil kesimpulan, bahwa: (1) tingkat kecemasan atlet aero modelling kelas free fligh tsetelah mengalami cedera bahu menjelang pertandingan di IST AKPRIND Flying Contest (IFC) tahun 2016 berada pada kategori sedang, (2) faktor kognitif atlet aero modelling kelas free flight setelah mengalami cedera bahu menjelang pertandingan di IST AKPRIND Flying Contest (IFC) tahun 2016 berada pada kategori "sedang”. (3) Pada faktor somatik atlet aero modelling kelas free flight setelah mengalami cedera bahu menjelang pertandingan di IST AKPRIND Flying Contest (IFC) tahun 2016 berada pada kategori "sedang". Simpulan dari hasil data yang dirata-rata tingkat kecemasan dari faktor kognitif dan somatik pada kategori "sedang". Berdasarkan uraian pendapat para ahli diatas, dapat ditarik kesimpulan bahwa gejala-gejala kecemasan sering dialami oleh atlet aeromodelling khususnya sebelum menghadapi pertandingan. Atlet akan merasa gelisah karena merasa takut tidak bisa memberikan yang terbaik dalam pertandingan, detak jantung semakin kencang ketika melihat penonton, bahkan sampai sering buang air besar maupun air kecil.

\section{DAFTAR PUSTAKA}

Ali Satia Graha. (2012). Identifikasi Macam Cedera pada Pasien Physical Therapy Clinic Fakultas Ilmu Keolahragaan Universitas Negeri Yogyakarta. Laporan Penelitian tidak dipublikasikan, Yogyakarta.

Andun Sudijandoko. (1999). Pencegahan dan Perawatan Cedera. Jakarta: Departemen Pendidikan Nasional.

Cerika Rismayanthi dan Yustinus Sukarmin. (2006). Usaha-Usaha Pencegahan Cedera Olahraga Pada Pemain Bola Basket. Yogyakarta: Medikora.

FASI. (2006). Aeromodelling. www. aeromodelling.or.id. diunduh tanggal 19 Januari 2016 pukul 21:33 WIB.

Febiaji. (2014). "Tingkat Kecemasan Atlet POMNAS XII Cabang Olahraga Sepak Bola Sebelum Menghadapi Pertandingan.” Skripsi. Yogyakarta: Fakultas Ilmu Keolahragaan Universitas Negeri Yogyakarta. 
Giam danTeh. (1993). Ilmu Kedokteran Olahraga. (Hartono Satmoko). Terjemahan .Jakarta: Binarupa Aksara.

HardiantoWibowo. (1995). Pencegahan dan Penatalakasanaan Cedera Olahraga. Jakarta: EGC.

Heil, J. (1993). Psychology of Sport Injury. Illinois: Human Kinetic

Husdarta, H.J.S. (2011). Psikologi Olahraga. Bandung: Alfabeta.

KartonoMohamad. (2005). PertolonganPertama. Jakarta: GramediaPustakaUtama.

Komarudin. (2015). Psikologi Olahraga Latihan KeterampilanMental dalam Olahraga Kompetitif. Bandung: PT REMAJA ROSDAKARYA.

Lilik Sudarwati. (2007). Kecemasan. Diunduh pada tanggal 12 April 2014, jam 17.00 WIB.

Pordirga Aeromodelling PB FASI. (2009). Buku Panduan Aeromodelling Indonesia. Jakarta.

Rizky Mahakharisma. (2014). "Tingkat Kecemasan Dan Stres Atlet Bulu Tangkis Menjelang Kompetisi Pomnas XII Tahun 2013 Di Daerah Istimewa Yogyakarta.” Skripsi. Yogyakarta: Fakultas Ilmu Keolahragaan Universitas Negeri Yogyakarta.

Roland P. Pfeiffer, dkk. (2009). Sports First Aid and Injury Prevention.Jakarta : PT. GeloraAksaraPratama.

Satiadarma, M.P. (2000). Dasar-dasar Psikologi Olahraga. Jakarta: Pustaka Sinar Harapan.

Singgih D. Gunarsa. (2008). Psiokologis Olahraga Prestasi. Jakarta: Gunung Mulia.

Sudibyo Setyobroto. (1993). Psikologi Olahraga. Jakarta: PT. Anem Kosong Anem.

Suftini. (2004). Macam-macam Cedera. http:/kidshealth. org/teen/foodfitness/exercise /sportsafety.html. Diunduh pada tanggal 15 Januari 2014 pukul 07.10 WIB.

Taylor. (1997). Macam-macam Cedera. http:/kidshealth. org/teen/foodfitness/exercisel sportsafety.html. Diunduh pada tanggal 15 Januari 2014 pukul 07.10 WIB.

Cedera pada Bahu. Diakses dalam http://doktertulangbelakangsingapura. com/kondisi/nyeribahu diunduh tanggal 7 April 2016. 